\title{
Analysis of Chemical Effect on Rigid Pavement
}

\author{
Akshay Bhange*,Kuldeep Dabhekar ${ }^{* *}$ Dr P.Y.Pawade ${ }^{* * *}$ \\ *-M-tech Transportation Engg-pursuing \\ ** Assistant Prof Civil Engineering Department, GHRCE, Nagpur, India \\ ***Assistant Professor and Head of Engineering Department, GHRCE, Nagpur, India
}

\begin{abstract}
Designing of pavement involves many variables like material, construction methods, loads, environment, and maintenance. Therefore various technical and economic factors must be known to design the pavement and also for its maintenance. But still the problem related to pavement maintenance are yet to be solved which arises due to the dynamic nature of road pavement where materials of these pavement are constantly changing. These materials deteriorate with time and therefore to be maintained in good condition requires substantial expenditure. At present there is a large emphasis on performance aspect of pavement, one such thought has lead to the development of Self Compacting Concrete.SCC is a new kind of High Performance Concrete (HPC) with excellent deformability and segregation resistance. It can flow through and fill the gaps of reinforcement and corner of moulds without any need for vibration and compaction during the placing process. Such concrete accelerates the placement, reduce the labour requirement needed for compaction and finishing.
\end{abstract}

Keywords: Durability, Pavement detoriation,mix design method.

\section{Introduction}

Cement based materials are the most abundant of all man made materials and are among the most important construction materials and it is most likely that they will continue to have the same importance in future.However these contructional and enginnering materials must meet new and higher demands. When facing issues of productivity,economy,quality and environment they have to compete with other construction materials such as plastic,wood,steel .One direction in this evolution is towards Self Compacting concrete(SCC) a modified product that without addtional compaction energy flows and consolidate under the influence of its own weight .

The use of SCC offers more industrialized production.Not only it will reduce the unhealthy asks for workers it can also reduce the technical cost of insitu cast concrete construction ,due to improved casting cycle quality,durability,surface finish and reliability of structures and eliminating some of the potential for human error .However SCC is a sensitive mix,strongly dependent on composition and the charactersitcs of its constituents it has to possess the incompatible properties of high flow ability together with high seggregation resistance . This balance is made possible by the dispersing effect of high range water reducing admixture(super plasticizer) combined with cohesiveness .

\section{Literature Review}

S Bhaskar,Ravindra Gettu , B.H Bharatkumar and M.Neelamegam(2012) reported the strength ,bond and durability related properties odf concrete with fly ash and silica fumes as cement replacement materails (CRM). It includes put out tests carried out following IS 2770(PartI) and RILEM. While the durability property obtained were on the expected lines, the bond performance in specimens with 30\% fly ash and $10 \%$ silica fumes showed lower strength with 6 to $16 \%$ variations compared.

A.Navaneeth Krishnan,V.M Shanthi(2012) evaluated performance of SCC by varying the percentage of silica fumes as replacement of cement.an attempt has been made to study the fresh and hardened properties of self compacting concrete with silica fumes as a mineral admixture a simple mix design for SCC proposed by Nan-Su method is used for fixing the trial mix.The trial mix which satisfied the fresh concrete properties as per ,EFNARC guideline and the one which gives maximum compressive strength is used in the present work.Cement is replaced with various percentages of silica fumes $(0 \%, 10 \%, 15 \%$ and $20 \%)$ self Compacting Concrete with $15 \%$ silica fumes showed better results when compared to other replacements, hence silica fumes can be effectively used for current replacement.

Increase in percentage of silica fumes $(10 \%, 15 \%$ and $20 \%)$ reduces the flow of concrete, SCC with $15 \%$ replacement of cement with silica fume showed good result both in comparison and tension.From the experimental investigation it is clear that cement can be replaced with $15 \%$ silica fumes effectivel in SCC.Thereby reducing the consumption of cement ,this in turn reduces the cost

Luiz Antonio Pereira de Olivieral ,Joiso the Castro Gourmet 2,Christiana Nadir Pererira3 represented the results of the sorptivity accomplished in mixtures of self compacting concrete with different types of additives and a normal concrete compacted by vibration. The self compacting concrete mixtures present slump 
flow of 650 to $50 \mathrm{~mm}$ and have the same cement contents.In the self compacting mixture,were used as additives,fly ash ,silica fumes hydraulic lime and a mixture of fly ash and hydrauliic lime.A modified carboxylates super plasticizer was used to obtain a specific workability. The capillary absorption was carried out out at 7,14 and 28 days of age through a methodolgy described in the work. The erezults permit to conclude that the used additives propitiate the self compacting concrete .In terms of capillary absorption,the mixtures with fly ash have a better performace.

\section{Test Method for Fresh SCC}

The main characterstics of SCC are the properties in the fresh state. SCC design mix is focussed on the ability to flow under its own weight wihout vibrations, the ability to flow through heavily congested re inforcement under its own weight,the ability to obtain homogenesity wothout segregation of aggregate.Several methods are available to evaluate these main charachterstic of SCC, these tests have not been standardized by National Organization .But EFNARC has suggested and standardized few tests.Following tests are used more enormously by researchers and concrete industries.

1.Slump Flow Test

2.U Box and L box test

3.Funnel Test

Table gives the recommended values for different tests given by different persons for mix to be characterized by

SCC.

\begin{tabular}{|l|l|l|}
\hline Sr no & Property & Range \\
\hline 1 & Slump test & $600-800 \mathrm{~mm}$ \\
\hline 2 & v-funnel & $6-12 \mathrm{sec}$ \\
\hline 3 & L box & $>0.8$ \\
\hline
\end{tabular}

\section{Work Carried Out}

The other work is carried out in the following ways:

a.Design of mix

b.Batching of ingredients

c.Mixing of ingredients

d.Self compactibility tests on mixes

e.Preparation of cubes and beams

f.Curing of cubes and beams

g.Testing of cubes and beams

\section{Mix Proportions}

Mix design for m40 grade of concrete as per IRC10262-2000

Table 1.Mix proportions for plain concrete

Mix design for SCC as perEFNRC

\begin{tabular}{|l|l|}
\hline Contents & Values \\
\hline Cement & $380 \mathrm{~kg} / \mathrm{m}^{3}$ \\
\hline Water & $140 \mathrm{~kg} / \mathrm{m}^{3}$ \\
\hline Fine Aggregates & $896 \mathrm{~kg} / \mathrm{m}^{3}$ \\
\hline Coarse Aggregates & $1140 \mathrm{~kg} / \mathrm{m}^{3}$ \\
\hline Admixture & $7 \mathrm{~kg} / \mathrm{m}^{3}$ \\
\hline
\end{tabular}

Table 2. Mix proportions for SCC

\begin{tabular}{|l|l|}
\hline Contents & Values \\
\hline Cement & $350 \mathrm{~kg} / \mathrm{m}^{3}$ \\
\hline GGBS & $60 \mathrm{~kg} / \mathrm{m}^{3}$ \\
\hline Water & $175 \mathrm{~kg} / \mathrm{m}^{3}$ \\
\hline Fine Aggregates & $900 \mathrm{~kg} / \mathrm{m}^{3}$ \\
\hline Coarse Aggregates & $810 \mathrm{~kg} / \mathrm{m}^{3}$ \\
\hline Admixture & $2.46 \mathrm{~kg} / \mathrm{m}^{3}$ \\
\hline
\end{tabular}


Mix proportions of SCC

Table 3. Various mix proportions for SCC

\begin{tabular}{|l|l|l|l|}
\hline Contents & Mix 1 & Mix 2 & Mix 3 \\
\hline Cement & $245 \mathrm{~kg} / \mathrm{m}^{3}$ & $210 \mathrm{~kg} / \mathrm{m}^{3}$ & $210 \mathrm{~kg} / \mathrm{m}^{3}$ \\
\hline GGBS & $165 \mathrm{~kg} / \mathrm{m}^{3}$ & $200 \mathrm{~kg} / \mathrm{m}^{3}$ & $100 \mathrm{~kg} / \mathrm{m}^{3}$ \\
\hline Fly ash & ----- & ------ & $100 \mathrm{~kg} / \mathrm{m}^{3}$ \\
\hline Water & $175 \mathrm{~kg} / \mathrm{m}^{3}$ & $175 \mathrm{~kg} / \mathrm{m}^{3}$ & $175 \mathrm{~kg} / \mathrm{m}^{3}$ \\
\hline Fine aggregates & $900 \mathrm{~kg} / \mathrm{m}^{3}$ & $900 \mathrm{~kg} / \mathrm{m}^{3}$ & $900 \mathrm{~kg} / \mathrm{m}^{3}$ \\
\hline Coarse aggregates & $810 \mathrm{~kg} / \mathrm{m}^{3}$ & $810 \mathrm{~kg} / \mathrm{m}^{3}$ & $810 \mathrm{~kg} / \mathrm{m}^{3}$ \\
\hline admixtures & $2.46 \mathrm{~kg} / \mathrm{m}^{3}$ & $2.46 \mathrm{~kg} / \mathrm{m}^{3}$ & $2.46 \mathrm{~kg} / \mathrm{m}^{3}$ \\
\hline
\end{tabular}

Table 4.Fresh properties of SCC mixes

\begin{tabular}{|l|l|l|l|}
\hline Mix code & $\begin{array}{l}\text { Flow } \\
(\mathbf{m m})\end{array}$ & $\begin{array}{l}\text { V } \\
\text { funnel(sec) }\end{array}$ & L box(H2/H1) \\
\hline Std mix & 650 & 9.4 & 0.9 \\
\hline Mix 1 & 680 & 9.3 & 0.88 \\
\hline Mix 2 & 690 & 9.1 & 0.92 \\
\hline Mix 3 & 690 & 8.8 & 0.95 \\
\hline
\end{tabular}

The results of the self compact ability tests are tabulated in table 4.As per EFNARC,time ranging from $6 \mathrm{sec}$ to $12 \mathrm{sec}$ is considered adequate for SCC. The V-funnel flow times werein the range of 9.4-8.8 seconds. Test results of this investigations indicated that all SCC mixes meet requirement of allowable flow time. Maximum size of aggregates was kept $20 \mathrm{~mm}$ in order to avoid blocking effect in L-box. The L-box ratio(H2/H1) was above 0.8 which was as per EFNARC. The all mix satisfied the acceptance criteria for self compacting concrete. Hence these mixes were chosen as the successful mixes, the cube and beams were casted for all the successful mixes and were tested for 28 days compressive strength.

\section{Compressive strength of SCC mixes}

Table and gives the cube compressive strength of the mixes. It can be seen that strength incresese with the increase in the GGBS contents. Three standard cubes for various mixes were tested to determine 7 days and 28 days compressive strength . compressive strength increases with the increase in the GGBS contents.

Depending upon the mineral admixtures,curing conditions,the result indicates that the mineral admixture helps in gaining of compressive strength. The compressive strength of SCC with fly ash and GGBS was greater than that of SCC with GGBS only.

Table 5. compressive strength of SCC mixes

\begin{tabular}{|l|l|}
\hline Samples & Strength $(\mathbf{M P a})$ \\
\hline Std mix & 52.50 \\
\hline Mix 1 & 54.68 \\
\hline Mix 2 & 56.98 \\
\hline Mix 3 & 59.00 \\
\hline
\end{tabular}

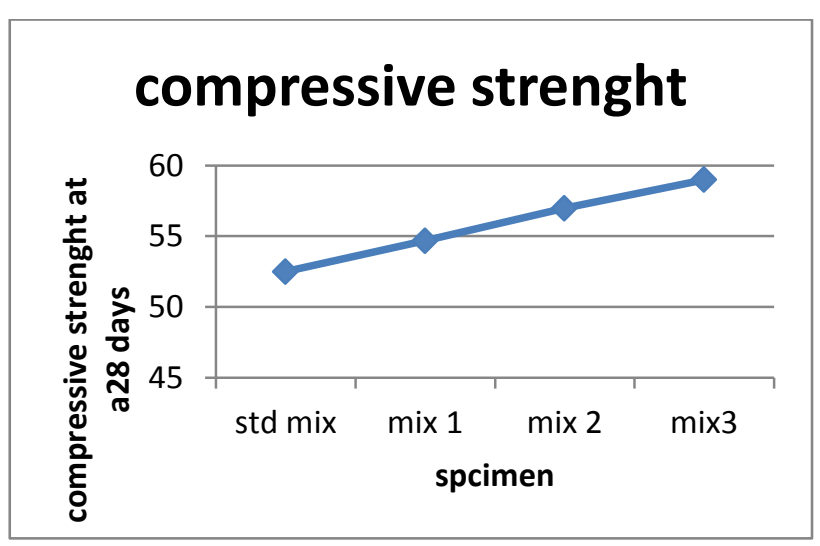

Figure 1. compressive strength of SCC

\section{Flexural strength}

The flexural strength results are shown in table. Three beams of each specimens of various mixes were tested for 7 days and 28 days. Flexrual strength decreses with the decrease in the cement content. 
Table 6. Flexrual strength of SCC mixes

\begin{tabular}{|l|l|}
\hline Samples & Strength (MPa) \\
\hline Std mix & 6.88 \\
\hline Mix 1 & 5.86 \\
\hline Mix 2 & 4.87 \\
\hline Mix 3 & 4.87 \\
\hline
\end{tabular}

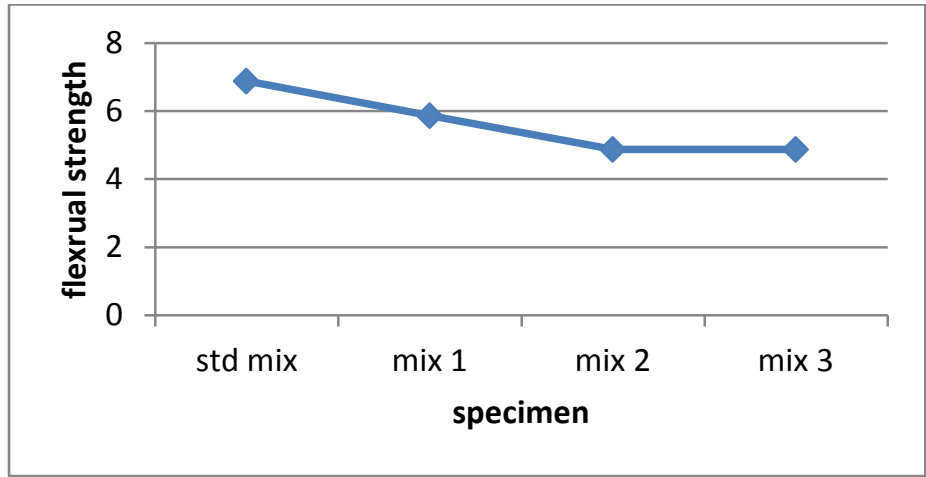

Figure 2.Flexrual strength of SCC mix

\section{Comparison of plain concrete with self compacting concrete}

The compressive strength of plain concrete was compared with self compacting concrete. Three cubes of each specimens were made and was cured in water for 28 days.

The compressive strength results indicates that the strength at 28 days curing of self compacting concrete was more as compare to plain concrete. Fig 3 shows the results of compressive strength of both the specimens.

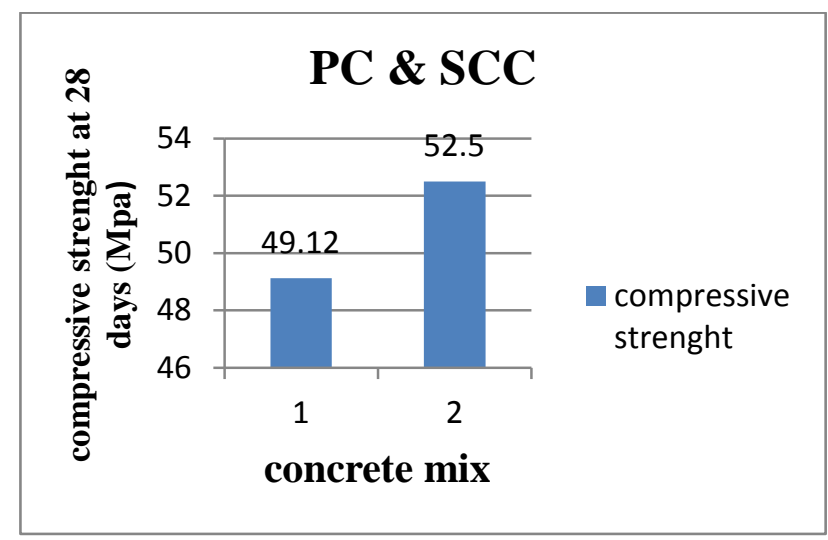

Fig 3 :Results of PC \& SCC mixes

\section{Sulphate Acid attack}

Concrete is susceptible to acid attack in terms of the strength loss after 28 days. Table and fig shows the decrease in the compressive strength of various mixes.

Average percentage loss in strength in SCC having both cementitous waste was recorded to be less as compare to other specimens.

Table 7. loss in compressive strength due to acid attack

\begin{tabular}{|l|l|l|l|}
\hline Mixes & Water cured & Acid cured & \%loss \\
\hline Mix 1 & $54.68 \mathrm{MPa}$ & $46.98 \mathrm{MPa}$ & 14.08 \\
\hline Mix 2 & $56.98 \mathrm{MPa}$ & $51.12 \mathrm{MPa}$ & 10.20 \\
\hline Mix 3 & $59 \mathrm{MPa}$ & $54 \mathrm{MPa}$ & 8.40 \\
\hline
\end{tabular}

It has been observed in from the table that the weight loss in GGBS mix only is high as compare to the mix having GGBS and Fly ash both. Table and Fig show the decrease in the weight of SCC mix specimens. 


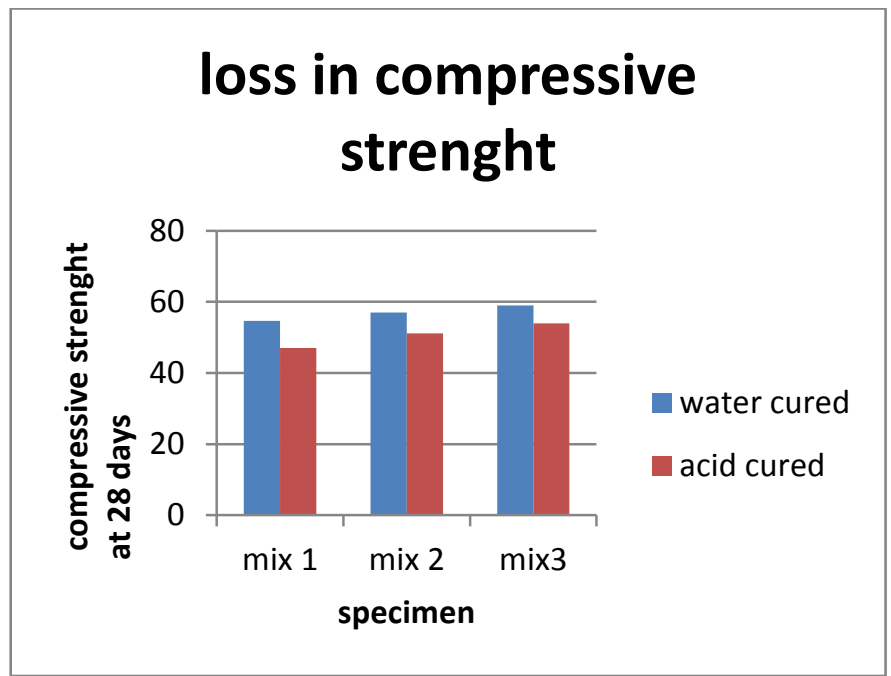

Figure 4:Loss in compressive strenght

Table 8.loss in weight of SCC mixes

\begin{tabular}{|l|l|l|l|}
\hline Mixes & $\begin{array}{l}\text { Initial } \\
\text { weight } \\
(\mathrm{Kg})\end{array}$ & $\begin{array}{l}\text { Final weight } \\
\text { after acid } \\
\text { curing(Kg) }\end{array}$ & $\begin{array}{l}\text { \%loss } \\
\text { in } \\
\text { weight }\end{array}$ \\
\hline Mix 1 & 2.460 & 2.418 & 1.7 \\
\hline Mix 2 & 2.726 & 2.681 & 1.63 \\
\hline Mix3 & 2.717 & 2.674 & 1.56 \\
\hline
\end{tabular}

\section{Chloride attack}

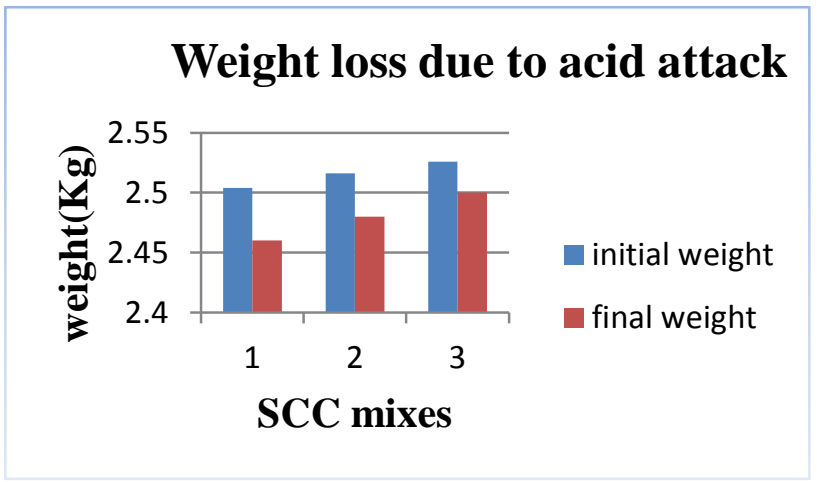

Figure 5:Weight loss due to acid attack

Sodium chloride neither react with calcium hydroxide nor with calcium hydrated aluminates. A loss in weight was noted in all the specimens which adversely affected the strength of concrete. Percentage loss in weight of each specimen was from $1 \%$ to $2 \%$.

It is evident that the pozzolanic material creates a more compact concrete. The effect of chloride decrease with the increases in the mineral admixture because they physically occupies pores in concrete by virtue of their particle size.

Table and fig show the decrease in the compressive strength of the SCC specimens. The strength of the SCC is not reduced to that extend as compare to acid attack.

Table 9. loss in strength due chloride attack

\begin{tabular}{|l|l|l|l|}
\hline Mixes & Water cured & Chloride cured & \%loss \\
\hline Mix 1 & $54.68 \mathrm{MPa}$ & $50.88 \mathrm{MPa}$ & 6.9 \\
\hline Mix 2 & $56.98 \mathrm{Mpa}$ & $53.98 \mathrm{MPa}$ & 5.2 \\
\hline Mix 3 & $59 \mathrm{MPa}$ & $57.12 \mathrm{MPa}$ & 3.1 \\
\hline
\end{tabular}




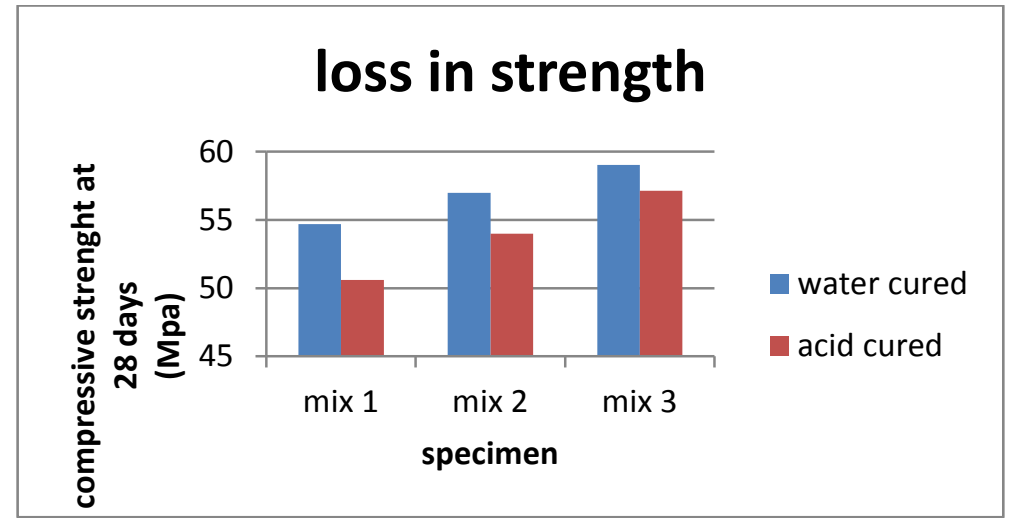

Figure 6:loss in strength due to chloride attack

Table and fig shows the decrease in the weight of the SCC mixes. It was observed that the weight loss in the specimen content more pozzolanic admixture was less as compared to other material

Table 10: loss in weight of SCC mixes

\begin{tabular}{|l|l|l|l|}
\hline Mixes & $\begin{array}{l}\text { Initial } \\
\text { weight }(\mathrm{Kg})\end{array}$ & Final weight $(\mathrm{Kg})$ & \%loss \\
\hline Mix 1 & 2.504 & 2.460 & 1.7 \\
\hline Mix 2 & 2.516 & 2.480 & 1.4 \\
\hline Mix 3 & 2.526 & 2.500 & 1.1 \\
\hline
\end{tabular}

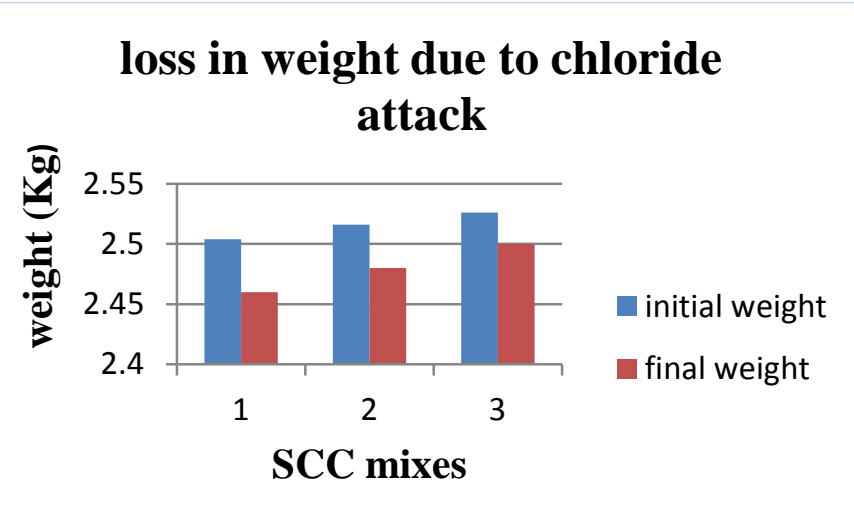

Figure 7:loss in weight due to chloride attack

\section{Conclusion}

Based on development of research work following conclusion have been drawn

1) The chloride permeability result shows that SCC having fly ash has superior performance in durability properties.

2) It has been observed that the weight loss is greater for test specimen of SCC containing GGBS only.

3) SCC with GGBS and fly ash shows good result in tension and compressions.

4) As water cement ratio reduces strength as well as durability increases in SCC with GGBS and fly ash.

5) Average compressive strength of SCC having GGBS and fly ash at 28 days increase by $25 \%$.

6) Average flexural strength of SCC specimens decrease with the decrease in the cement contents.

7) Durability of SCC with GGBS and fly ash is more as compare to other mixes.

8)SCC with GGBS and fly ash can resists sulphate attack as well.

\section{References:}

[1]. Kazim Turk,Sinan caliskan,"Capillary waterabsorption of self compacting concrete under different curing condition",Indian journal of Engineering,Vol.14october2007,365-372.

[2]. S.Bhaskar,Ravinder Gettu,B.H Bharatkumar,"Strenght bond and durability related properties of concrete with mineral admixtures", The Indian concrete journal,february2012,09-15.

[3]. Md.safiudin,J.S West and K.A Soudki,"Durability performance of self

[4]. Compacting concrete",journal of civil engg, 1834-1840.

[5]. Pratibha Aggarwal,S.M.Gupta,"Properties of self compacting concrete-An overview"Journal of civil engineering,2324August2005,Singapore.

[6]. The Europian guidelines by EFNARC for SCC,May2005. 
[7]. Assaad, J. J., and Khayat, K. H., "Effect of Mixture Consistency on Formwork Pressure Exerted by Highly Flowable

[8]. Concrete", Journal of Materials in Civil Engineering, Vol. 18, No. 6, December 1, 2006b.

[9]. Assaad, J.J., and Khayat, K.H., "Effect of Viscosity-Enhancing Admixtures on Formwork Pressure and Thixotropy of SelfConsolidating Concrete", ACI Materials Journal, V. 103, No. 4,July-August 2006. 